\title{
Ceruloplasmin levels in human sera from various diseases and their correlation with patient's age and gender
}

\author{
Viorica Lopez-Avila ${ }^{1^{*}}$, William H. Robinson ${ }^{2}$, Kirk Lokits ${ }^{3}$ \\ ${ }^{1}$ Agilent Technologies, Santa Clara, CA, USA; Corresponding author: viorica lopez-avila@,agilent.com \\ ${ }^{2}$ Stanford University, Stanford, CA, USA \\ ${ }^{3}$ University of Cincinnati, Cincinnati, OH, USA; Present address: Midwest Research Institute, 425 Volker Blvd, Kansas City, MO, USA
}

Received 7 July 2009; revised 5 August 2009; accepted 7 August 2009.

\begin{abstract}
Ceruloplasmin (Cp), a copper metalloprotein in human serum has been a valuable diagnostic marker in Wilson's disease where $\mathrm{Cp}$ levels tend to be low while high levels in serum were associated with myocardial infarction, neoplastic and inflammatory conditions. There is no standardized reference method for $C p$ and current immunologic and bichromatic assays have a number of drawbacks. The method described here uses immunoaffinity chromatography to remove six of the most abundant proteins from a serum sample and high-pressure liquid chromatography (HPLC) with a size-exclusion column to separate $\mathrm{C} p$ from other serum proteins and any free $\mathrm{Cu}$ prior to analysis of ${ }^{63} \mathrm{Cu}$ and ${ }^{65} \mathrm{Cu}$ by inductively-coupled plasma mass spectrometry (ICPMS). Identification of $\mathrm{Cp}$ is based on retention time match of the unknown protein in the serum sample with the Cp external standard and the presence of ${ }^{63} \mathrm{Cu}$ and ${ }^{65} \mathrm{Cu}$ at a ratio of $2.2 \pm 0.1$. The method accuracy, as established independently by two of the authors with a reference serum certified for $\mathrm{Cp}$, is 98 to $101 \%$ and the coefficient of variation is $6.4 \%$ and $5.4 \%$, respectively. The assay was used to analyze a total of 167 human sera for $\mathrm{Cp}$ from patients with myocardial infarction (MI), pulmonary embolism (PE), rheumatoid arthritis (RA), systemic lupus erythematosus (SLE), other forms of arthritis, and a set of healthy patients as normal controls (NC). Our data show that $\mathrm{Cp}$ concentrations tend to be higher in MI, RA, and SLE patients, higher in female as compared to male patients, and we did not observe a correlation between $\mathrm{Cp}$ concentration and patient's age for the set of $\mathbf{7 0}$ patients for which we had gender and age information.
\end{abstract}

Keywords: Ceruloplasmin; HPLC-ICPMS; Immunoaffinity Chromatography

\section{INTRODUCTION}

Ceruloplasmin $(\mathrm{Cp})$ is a blue alpha-2 glycoprotein with a molecular weight of $132,000 \mathrm{u}$ [1]. It binds $90-95 \%$ of blood plasma copper $(\mathrm{Cu})$, has 6-7 $\mathrm{Cu}$ ions per molecule (1) and exhibits ferroxidase activity [1,2], amine oxidase activity [1], superoxidase activity [1] as well as it is involved in $\mathrm{Cu}$ transport and homeostasis [1]. Hellman and Gitlin, however, reported that $\mathrm{Cp}$ plays no essential role in the transport and metabolism of $\mathrm{Cu}$ [2] and in a separate study [3] reported that analysis of $\mathrm{Cu}$ incorporation into apoceruloplasmin (apoCp) in vitro showed that failure is intrinsic to mutant proteins. Linder et al. [4] claim that newly absorbed dietary $\mathrm{Cu}$ is transported by plasma protein cariers (i.e., albumin, transcuprein, and $\mathrm{Cp}$ ) from intestine to liver and kidney, and that $\mathrm{Cp}$ is involved primarily in transport of $\mathrm{Cu}$ from liver to other organs. Prohanska and Gybina [5] provide details on the transport process in which $\mathrm{Cu}$, imported by plasma membrane protein $\mathrm{Ctr} 1$, binds to $\mathrm{Cu}$ chaperone proteins like Atox 1, which then docks with ATP7B and delivers $\mathrm{Cu}$ to plasma $\mathrm{Cp}$.

Current analytical procedures for the determination of $\mathrm{Cp}$ include immunoturbidimetry and nephelometry [6], in which $\mathrm{Cp}$ is reacted with anti-Cp antibodies to give insoluble aggregates whose absorbance is proportional to the concentration of $\mathrm{Cp}$ in the sample [6], radial immunodifussion (RID) test [7], and bichromatic assay [8]. When comparing RID with immunonephelometry a significant bias was found that was in part attributed to the variation in the antisera sources used in the two methods [7]. In the case of the bichromatic method, the procedures are based on the oxidase activity of $\mathrm{Cp}$ on diamines such as benzidine. The bichromatic method requires special precautions (i.e., benzidine is a known 
carcinogen) and purification of substrates [9], detects only $\mathrm{Cp}$ and not the apoCp [10], and it is not very effective since $\mathrm{Cp}$ does not have its own substrate [11]. The immunologic methods also have drawbacks because antisera cross-react with apoCp thus giving higher concentrations for Cp [9]. Evidence suggests that patients with Wilson's disease may have exhibited normal serum concentrations of $\mathrm{Cp}$ because the immunologic assay could not distinguish between the apoCp and Cp [10]. In general, a normal person has 0.2 to $0.5 \mathrm{mg} / \mathrm{mL}$ of $\mathrm{Cp}$ in serum [11].

Although low serum concentration of $\mathrm{Cp}$ has been an important diagnostic indicator of Wilson's disease [10], high $\mathrm{Cp}$ concentrations were reported in patients with macular degenerations as compared with controls (i.e., $\mathrm{Cp}$ concentration $0.691 \pm 0.153 \mathrm{mg} / \mathrm{mL}$ vs $0.312 \pm 0.064$ $\mathrm{mg} / \mathrm{mL}$ ) by Newsome et al. [12], in patients with MI by Reunanen et al. [13], and in a variety of neoplastic and inflammatory conditions like carcinomas, leukemia, Hodgkin disease, primary biliary cirrhosis, systemic lupus erythematosus, and rheumatoid arthritis [14].

This paper describes the peer verification of a new method for the determination of $\mathrm{Cp}$ in human serum at biologically relevant concentrations $>0.01 \mathrm{mg} / \mathrm{mL}$ using a reference serum certified for $\mathrm{Cp}$ and a set of $167 \mathrm{hu}-$ man sera from several diseases. This method, which was published recently [15], uses HPLC to separate Cp from other proteins including transcuprein (molecular weight $270,000 \mathrm{u}$ ) and from inorganic ions, and ICPMS to detect $\mathrm{Cu}$ isotopes at mass-to-charge $(\mathrm{m} / \mathrm{z})$ ratios of 63 and 65 , and to identify $\mathrm{Cp}$ from the HPLC retention time and the signal ratios of $\mathrm{Cu}$ isotopes ${ }^{63} \mathrm{Cu}$ and ${ }^{65} \mathrm{Cu}$ measured with ICPMS. To eliminate possible interference from highly abundant proteins, some of which may bind $\mathrm{Cu}$ to form protein- $\mathrm{Cu}$ complexes, the serum sample is first depleted of albumin, IgG, IgA, transferrin, haptoglobin, and anti-trypsin using immunoaffinity chromatography prior to HPLC. Quantitation of Cp in the depleted serum is performed by external standard calibration with a $\mathrm{Cp}$ standard.

\section{EXPERIMENTAL}

Materials: the standard of $\mathrm{Cp}$ purified from human plasma was from EMD Biosciences/Calbiochem (La Jolla, CA) in lyophilized form from $133 \mu \mathrm{L}$ of $50 \mathrm{mM}$ potassium phosphate, $\mathrm{pH} 6.8,100 \mathrm{mM}$ potassium chloride, $200 \mathrm{mM}$-amino-n-caproic acid and 5mM EDTA, with a purity of $>95 \%$. The 167 serum samples were as follows: 37 patients with MI, 50 with RA, 24 with SLE, 8 with $\mathrm{PE}, 16 \mathrm{NC}$, and 32 sera (identified as "other" in this paper) were from patients with different forms of arthritis: osteoarthritis, juvenile rheumatoid arthritis, reactive arthritis, inflammatory arthritis; myositis and dermatomyositis, fibromyalgia, anthralgia, ankylosing spondilitis, spinal stenosis, Sjogren, Reiter's syndrome, connective tissue disease, scleroderma, polymyalgia rheumatica and palindromic rheumatism gout and CREST syndrome.

ERM DA470 is a human serum certified for 15 proteins including $\mathrm{Cp}[16,17]$ and was purchased from RTC (Laramie, WY).

Serum preparation: all human samples were collected and utilized under Institutional Review Board approved protocols and with informed consent. To summarize, blood samples were withdrawn using sterile conditions and allowed to clot at room temperature for a minimum of $10 \mathrm{~min}$. Serum was separated by centrifugation for $10 \mathrm{~min}$ at $4000 \mathrm{rpm}$, divided among several vials to minimize freeze-thawing, and kept at $-80^{\circ} \mathrm{C}$ until analysis.

Immunoaffinity chromatography: high-abundant protein removal from human serum was performed on a 4.6 x $100 \mathrm{~mm}$ immunodepletion column (Agilent Technologies) with a capacity of $40 \mu \mathrm{L}$ of non-diluted human serum (capacity is defined as the amount of original serum that can be loaded onto the column such that $99 \%$ of the targeted high-abundant proteins are removed for at least 200 injections on a particular column). After a 5fold dilution of serum sample with buffer $A$ and filtration through a $0.22 \mu \mathrm{m}$ spin filter, $150 \mu \mathrm{L}$ of the diluted sample was injected onto the column in $100 \%$ Buffer $\mathrm{A}$ at a flow rate of $0.5 \mathrm{~mL} / \mathrm{min}$ for $10.0 \mathrm{~min}$. After collection of the flow-through fraction $(2 \mathrm{~mL})$, the column was washed and the bound proteins were eluted with $100 \%$ Buffer B at a flow rate of $1.0 \mathrm{~mL} / \mathrm{min}$ (volume of bound protein fraction $3 \mathrm{~mL}$ ). The immunoaffinity column was then regenerated by equilibrating it with Buffer $\mathrm{A}$ for 13 min bringing the total run cycle to $30.0 \mathrm{~min}$. Fraction collection of flow-through proteins was time-controlled and corresponded to the UV $280 \mathrm{~nm}$ absorbance of the eluting proteins. The flow-through fraction was collected and kept at $4^{\circ} \mathrm{C}$ using the thermostatted fraction collector, was reduced to a final volume of $30 \mu \mathrm{L}$ using spin concentrators and analyzed by HPLC-ICPMS. Bound proteins (i.e., albumin, IgG, IgA, transferin, haptoglobin and anti-trypsin) were eluted from the immunodepletion column and selected samples were analyzed by ICPMS (data not included here). Buffer $\mathrm{A}$ is a phosphate buffer (pH 7.4) and buffer $B$ is a concentrated urea buffer in water ( $\mathrm{pH} 2.25)$.

Instrumentation: An Agilent 1100 LC system equipped with a binary pump, degasser, autosampler (300 $\mu \mathrm{L}$ loop) with thermostat, diode array detector with $6 \mathrm{~mm}$ flow cell, and a thermostated fraction collector was used for the immunodepletion work. Protein separation was achieved on a silica TSKGel column SW3000 $(30 \mathrm{~cm} \times 4.6 \mathrm{~mm}$ id $\times 4 \mu \mathrm{m}$ particles $\times 250 \mathrm{~nm}$ pore size) 
from Tosoh Bioscience (Montgomerryville, PA). All HPLC analyses were performed on an Agilent Technologies 1100 Series High Performance Liquid Chromatography system equipped with a binary pump, degasser, autosampler (100 $\mu \mathrm{L}$ loop) and diode array detector $(215 \mathrm{~nm}$ and $280 \mathrm{~nm}) .0 .1 \mathrm{M}$ Tris $(\mathrm{pH} \mathrm{7})$ was used as mobile phase at a flow rate of $0.3 \mathrm{~mL} / \mathrm{min}$. The liquid flow from the HPLC column was converted into aerosol droplets by a Micromist nebulizer with a dual pass spray chamber. ${ }^{63} \mathrm{Cu}$ and ${ }^{65} \mathrm{Cu}$ scan was performed on an Agilent 7500ce ICPMS system with a quadrupole mass analyzer and an Octapole Reaction System (ORS) for matrix-based interference removal. High levels of $\mathrm{Na}$ in the sample can cause the formation of ${ }^{40} \mathrm{Ar}{ }^{23} \mathrm{Na}$ polyatomic species that overlap with ${ }^{63} \mathrm{Cu}$. Similarly, ${ }^{31} \mathrm{P}$ based molecular species $\left({ }^{31} \mathrm{P}{ }^{16} \mathrm{O}{ }^{16} \mathrm{O}\right.$ and $\left.{ }^{31} \mathrm{P}{ }^{18} \mathrm{O}{ }^{16} \mathrm{O}\right)$ can overlap with the ${ }^{63} \mathrm{Cu}$ and ${ }^{65} \mathrm{Cu}$ isotopes. The ORS with $\mathrm{He}(99.999 \%$ purity) as collision gas at $3.5 \mathrm{~mL} / \mathrm{min}$ was used to eliminate these interfering species and to improve signal to noise. ICPMS conditions: outer gas ( $\mathrm{Ar})$ flowrate $15 \mathrm{~L} / \mathrm{min}$; carrier gas (Ar) flowrate $0.8 \mathrm{~L} / \mathrm{min}$; makeup gas (Ar) flowrate $0.15 \mathrm{~L} / \mathrm{min}$; RF power $1.55 \mathrm{~kW}$, sampling depth $8 \mathrm{~mm}$.

\section{RESULTS AND DISCUSSION}

\subsection{Method Performance}

The performance of this method (see Table 1) was established independently by two of the authors (in separate laboratories) with a reference human serum ERM DA470 that is certified for $\mathrm{Cp}$ at $0.205 \mathrm{mg} / \mathrm{mL}$ using identical instrumentation. This serum was reconstituted with high purity water and analyzed in triplicate in Laboratory 1 and in seven replicates over a period of two months in Laboratory 2 . The results are summarized in Table 1. The agreement between the concentration of $\mathrm{Cp}$ in the certified serum and the reconstituted serum analyzed by this method is excellent (method accuracy is $101 \%$ in Laboratory 1 and $98.0 \%$ in Laboratory 2). The coefficient of variation $(\mathrm{CV})$ for the three replicate measurements of the freshly reconstituted serum in Laboratory 1 is $5.4 \%$. The CV of the seven replicates performed over a period of two months in Laboratory 2 is $6.4 \%$.

Method performance data are included in Table 2. The method detection limit was established from the instrument detection limit and applies only to sample injection volumes of $5 \mu \mathrm{L}$; larger injection volumes would allow a lower method detection limit but such experiments were not pursued here. The method dynamic range is given as 0.01 to $5 \mathrm{mg} / \mathrm{mL}$ since this is the range of concentrations that were tested here. Although the instrument dynamic range is 9 orders of magnitude, that would involve adjustments in ICPMS operating parameters to accommodate such a wide range. Expected
Table 1. Concentration of Cp in the ERM DA 470 reference serum.

\begin{tabular}{cccc}
\hline & $\begin{array}{c}\text { Certified } \\
\text { value } \\
(\mathbf{m g} / \mathbf{m L})\end{array}$ & $\begin{array}{c}\text { Conc meas- } \\
\text { ured in this } \\
\text { study } \\
(\mathbf{m g} / \mathbf{m L})\end{array}$ & ${ }^{{ }^{63} \mathbf{C u} /{ }^{65} \mathbf{C u}}$ \\
\hline $\begin{array}{c}\text { ERM DA 470 } \\
\text { Reference Serum } \\
(\text { Laboratory 1) }\end{array}$ & $\begin{array}{c}0.205 \\
(0.011)^{\mathrm{a}}\end{array}$ & $0.208(5.4 \%)^{\mathrm{b}}$ & $2.1(3.6 \%)^{\mathrm{b}}$ \\
$\begin{array}{c}\text { ERM DA 470 } \\
\text { Reference Serum } \\
\text { (Laboratory 2) }\end{array}$ & $\begin{array}{c}0.205 \\
(0.011)^{\mathrm{a}}\end{array}$ & $0.201(6.4 \%)^{\mathrm{c}}$ & $2.2(7.3 \%)^{\mathrm{c}}$ \\
\hline
\end{tabular}

${ }^{\mathrm{a}}$ Uncertainty $(\mathrm{mg} / \mathrm{mL})$ - defined as half-width of the $95 \%$ confidence interval of the mean value( $\mathrm{K}$ factors were chosen according to the $\mathrm{t}$-distribution depending on the number of labs) $[12,13]$.

${ }^{\mathrm{b}}$ Average of 3 determinations; value given in parentheses is the coefficient of variation.

${ }^{c}$ Average of 7 determinations; value given in parentheses is the coefficient of variation.

Table 2. Cp determination by HPLC-ICPMS-method performance ${ }^{\mathrm{a}}$.

\begin{tabular}{|c|c|}
\hline Method indicator & Value \\
\hline Detection Limit & $0.01 \mathrm{mg} / \mathrm{mL}$ \\
\hline Dynamic Range & $\begin{array}{c}0.01-5.0 \mathrm{mg} / \mathrm{mL} \text { (tested only until } 5 \\
\mathrm{mg} / \mathrm{mL} \text { ) }\end{array}$ \\
\hline Reproducibility & $\begin{array}{l}\text { CV for immunodepletion : } 0.07 \% \text { to } 2.2 \% \\
\text { CV for injection into HPLC: } 5.3 \% \\
\text { (Cp standard at } 1 \mathrm{mg} / \mathrm{mL}) \\
\text { Overall CV: }<10 \%\end{array}$ \\
\hline $\begin{array}{l}\text { Accuracy using } \\
\text { ERMDA470 }\end{array}$ & $\begin{array}{l}101 \% \text { (Laboratory } 1) \\
98.0 \% \text { (Laboratory } 2)\end{array}$ \\
\hline Cp Identification & $\begin{array}{l}\text { from retention time match of the unknown } \\
\text { peak in the sample to the } \mathrm{Cp} \text { standard and } \\
\text { the presence of }{ }^{63} \mathrm{Cu} \text { and }{ }^{65} \mathrm{Cu} \text { at a ratio of } \\
\qquad 2.2 \pm 0.1\end{array}$ \\
\hline
\end{tabular}

${ }^{\mathrm{a}}$ This method takes approximately $95 \mathrm{~min} / \mathrm{sample}$ from start to finish (15 min dilution and filtration, $30 \mathrm{~min}$ immunoaffinity chromatography, 20-30 min concentration, and 20 min HPLC-ICPMS analysis).

concentrations of $\mathrm{Cp}$ in human sera are in the 0.1-2 $\mathrm{mg} / \mathrm{mL}$ range, therefore a $30 \mu \mathrm{L}$ volume of the original serum is sufficient to detect $\mathrm{Cp}$ at $0.1 \mathrm{mg} / \mathrm{mL}$ if the final volume of the depleted serum is $30 \mu \mathrm{L}$. The overall $\mathrm{CV}$ for method reproducibility is $<10 \%$ and it is shown in Table 2 for various steps in the analysis. The identification of $\mathrm{Cp}$ is based on retention time match of the unknown peak in the sample to the $\mathrm{Cp}$ standard and the ratio of ${ }^{63} \mathrm{Cu} /{ }^{65} \mathrm{Cu}$. The average HPLC retention time for 8 consecutive injections of the Cp standard is $8.389 \mathrm{~min}$ with a $\mathrm{CV}$ of $0.059 \%$. The relative abundance of the ${ }^{63} \mathrm{Cu}$ is $69.17 \%$ and ${ }^{65} \mathrm{Cu}$ is $30.83 \%$, thus the theoretical ratio for ${ }^{63} \mathrm{Cu} /{ }^{65} \mathrm{Cu}$ is 2.24; based on our experimental data we set the acceptance limits for ${ }^{63} \mathrm{Cu} /{ }^{65} \mathrm{Cu}$ to $2.2 \pm$ $0.1[15]$.

In addition, we validated the $\mathrm{Cp}$ measurements by performing a total $\mathrm{Cu}$ analysis on a set of 23 depleted sera and compared those measurements with the $\mathrm{Cp}$ concentrations measured by HPLC-ICPMS (see Figure 1). Regression analysis gave a correlation coefficient of 
0.9, which confirms literature reports that most $\mathrm{Cu}$ in depleted serum is bound by $\mathrm{Cp}$ [1]. Furthermore, we verified the number of $\mathrm{Cu}$ atoms bound by $\mathrm{Cp}$ in the ERM DA470 reference serum by determining the total $\mathrm{Cu}$ in the depleted sample. At a $\mathrm{Cp}$ concentration of 0.2

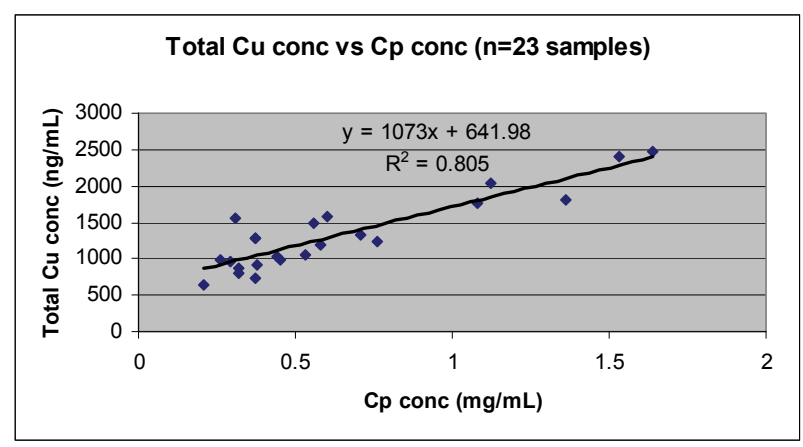

Figure 1. Total $\mathrm{Cu}$ vs $\mathrm{Cp}$ concentration for 23 serum samples (7 PE, $1 \mathrm{NC}, 14 \mathrm{MI}$ and ERM DA470).

Cp standard @1.3 mg/mL
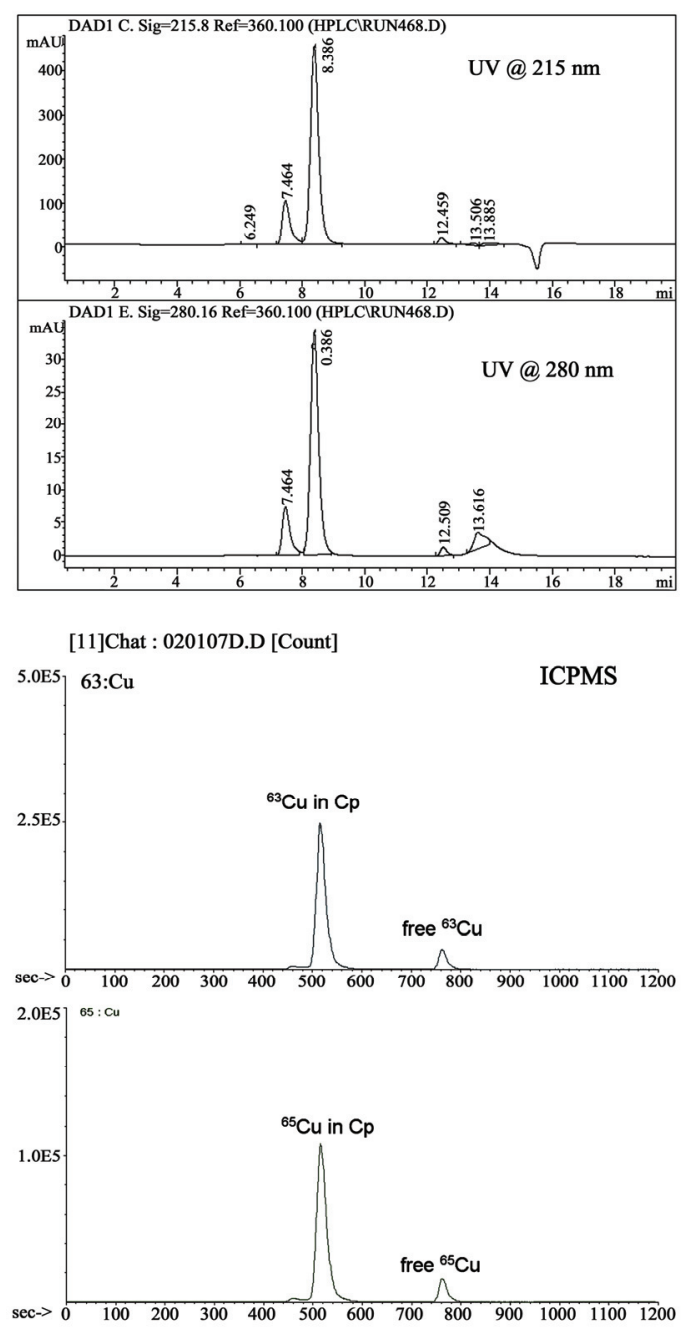

$\mathrm{mg} / \mathrm{mL}$ (measured in this study for the ERM DA470 serum), $6 \mathrm{Cu}$ atoms per $\mathrm{Cp}$ molecule would correspond to a total $\mathrm{Cu}$ concentration of $596 \mathrm{ng} / \mathrm{mL}$ and $7 \mathrm{Cu}$ atoms per $\mathrm{Cp}$ molecule would correspond to $695 \mathrm{ng} / \mathrm{mL}$. Because the total $\mathrm{Cu}$ measured in the depleted reference serum was in the range of $618-661 \mathrm{ng} / \mathrm{mL}$, we concluded that $\mathrm{Cp}$ must contains between 6 and 7 atoms per molecule, consistent with the published data for Cp [1] Also as part of method validation, a $\mathrm{Cp}$ standard, the ERMDA470 certified serum and one of the depleted MI sera were fractionated by HPLC and the corresponding fractions containing $\mathrm{Cp}$ were collected manually, and were then subjected to one gel electrophoresis followed by $\mathrm{Cp}$ band excision, in-gel digestion, and electrospray $\mathrm{MS}$ of the digest to confirm the presence of $\mathrm{Cp}$ [15].

Figure 2 shows HPLC-UV and ICPMS chroma tograms for a $\mathrm{Cp}$ standard and a depleted serum sample; the HPLC chromatograms show the complexity of the
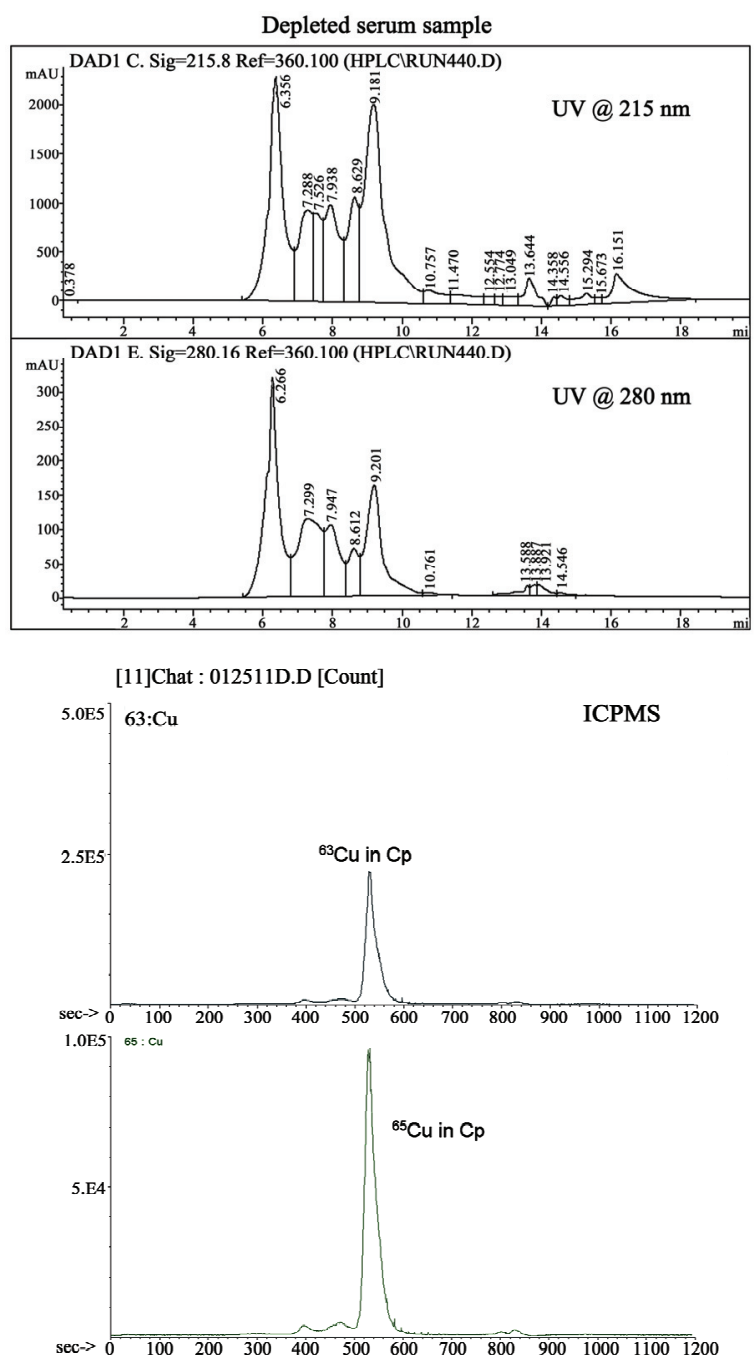

Figure 2. HPLC-ICPMS chromatograms for Cp standard and depleted serum sample. 
serum sample even after its depletion of the high abundant proteins whereas the ICPMS chromatograms show only the ${ }^{63} \mathrm{Cu}$ and ${ }^{65} \mathrm{Cu}$ signals at a retention time that matches that of the $\mathrm{Cp}$ standard and are in a ratio corresponding to 6-7 $\mathrm{Cu}$ atoms per $\mathrm{Cp}$ molecule.

\subsection{Ceruloplasmin Levels in Sera from Different Diseases}

Figure 3 shows the distribution of $\mathrm{Cp}$ concentration across several diseases, including MI, PE, RA, SLE, other forms of arthritis (i.e., osteoarthritis, juvenile rheumatoid arthritis, reactive arthritis, inflammatory arthritis) and NC sera (167 serum samples in all). Samples derived from patients experiencing MI (37 in our study) had an average Cp concentration of $0.402 \pm 0.377$ $\mathrm{mg} / \mathrm{mL}$ and exhibited $\mathrm{Cp}$ concentrations as high as 1.64 $\mathrm{mg} / \mathrm{mL}$, while a subset of 50 RA patients and 24 SLE patients had average concentrations of $0.447 \pm 0.215$ $\mathrm{mg} / \mathrm{mL}$ and $0.426 \pm 0.264 \mathrm{mg} / \mathrm{mL}$ and exhibited elevated $\mathrm{Cp}$ concentrations as high as $1.23 \mathrm{mg} / \mathrm{mL}$ and 1.24 $\mathrm{mg} / \mathrm{mL}$, respectively (Figure 3). Normal Cp concentrations are in the $0.2-0.5 \mathrm{mg} / \mathrm{mL}$ range [11] and the average $\mathrm{Cp}$ concentration in the set of $\mathrm{NC}$ sera in our study (16 patients) was $0.316 \pm 0.120 \mathrm{mg} / \mathrm{mL}$. When comparing $\mathrm{Cp}$ concentrations for our MI, RA, SLE, and "other"sera with our set of NC sera, only the RA and SLE data were statistically different from the $\mathrm{NC}$ in a $\mathrm{t}$ test (i.e., p values were 0.0037 and 0.0837 for RA and SLE sera, respectively). The MI data reported here show a much higher variation than our NC data, and this variation is statistically significant ( $\mathrm{F}$ value is $9.92, \mathrm{~F}$ crit is 2.22, and $\mathrm{p}<0.001)$. Reunanen et al. [13], using serum from 104 patients with MI or stroke and 104 matched controls, concluded that high $\mathrm{Cp}$ concentrations in serum were significantly associated with higher incidents of MI but not of stroke.

Hantzschel et al. [18] reported for RA and polymyalgia rheumatica an average $\mathrm{Cp}$ concentration for $23 \mathrm{RA}$ patients ( 22 females) of $0.7 \pm 0.4 \mathrm{mg} / \mathrm{mL}$ and for 16 polymyalgia rheumatica patients (all females) $0.5 \pm 0.1$ $\mathrm{mg} / \mathrm{mL}$. The authors suggested that clinical data, including a history of hip and shoulder muscle tenderness and lack of positive rheumatoid factor, and a normal $\mathrm{Cp}$ level could distinguish polymyalgia rheumatica from rheumatoid arthritis. We observed a similar trend for RA patients as compared with patients with "other" forms of arthritis. The average $\mathrm{Cp}$ concentrations for RA of 0.447 $\pm 0.215 \mathrm{mg} / \mathrm{mL}$ were significantly different from the average Cp concentrations for "other" diseases, which had an average $\mathrm{Cp}$ concentration of $0.376 \pm 0.145$ $\mathrm{mg} / \mathrm{mL}$, only when doing a one-tail test ( $\mathrm{p}$ value was 0.041). Perhaps $\mathrm{Cp}$ concentrations above $0.5 \mathrm{mg} / \mathrm{mL}$ would be indicative of disease severity, however characterization of larger sample sets will be necessary to substantiate this observation.
Figures 4 and $\mathbf{5}$ show $\mathrm{Cp}$ concentrations as a function of patient's gender and age, respectively. Although this is a very limited sample set (70 sera from 33 RA, 5 SLE and 32 "other"arthritis patients with 49 females and 21 males) it is interesting to note that female patients exhibited slightly higher $\mathrm{Cp}$ concentrations (ave $\pm \mathrm{SD}$ of $0.392 \pm 0.153 \mathrm{mg} / \mathrm{mL})$ than male patients $(0.319 \pm 0.123$ $\mathrm{mg} / \mathrm{mL})$ that were statistically significant at $5 \%$ significance level (48 degrees of freedom, $\mathrm{t}_{\text {stat }}$ 2.104, $\mathrm{t}_{\text {crit }} 2.011$, probability for a two-tail test was 0.0410). However, when we averaged only the $\mathrm{Cp}$ concentrations for the 33 RA patients by gender ( 24 females and 9 males) we found a larger difference between the female patients and male patients $(0.417 \pm 0.158 \mathrm{mg} / \mathrm{mL}$ vs $0.278 \pm$ $0.096 \mathrm{mg} / \mathrm{mL}$, respectively) that was statistically significant at 5\% significance level (24 degrees of freedom, $\mathrm{t}_{\text {stat }}$ 3.059, $\mathrm{t}_{\text {crit }} 2.064$, probability for a two-tail test was 0.005 ). Data reported by Lyngbye and Kroll [19] for a normal population (280 patients, 149 males and 111 females) also indicate significantly higher concentrations of $\mathrm{Cp}$ in female patients which are known to be caused by use of oral contraceptives [20].

There does not seem to be a correlation between the $\mathrm{Cp}$ concentration and patient's age across these 70 patients with RA and arthritis (Figure 5). The average $\mathrm{Cp}$ concentration for RA patients was $0.370 \pm 0.149 \mathrm{mg} / \mathrm{mL}$ and $0.384 \pm 0.163 \mathrm{mg} / \mathrm{mL}$ for $<50$ y.o. and $>50$ y.o., respectively ( $\mathrm{t}_{\text {stat }}$. of 0.247 is less than $\mathrm{t}_{\text {crit }} 2.059, \mathrm{p}$ for a two-tail test was 0.807 , indicating that the results were not statistically different). The average $\mathrm{Cp}$ concentrations for "other" arthritis patients were $0.387 \pm 0.162$ $\mathrm{mg} / \mathrm{mL}$ and $0.356 \pm 0.110 \mathrm{mg} / \mathrm{mL}$ for $<50$ y.o. and $>50$ y.o., respectively $\left(\mathrm{t}_{\text {stat }} .0 .645\right.$ is less than $t_{\text {crit }} 2.048$, $p$ for a two-tail test was 0.524 ), indicating again that the

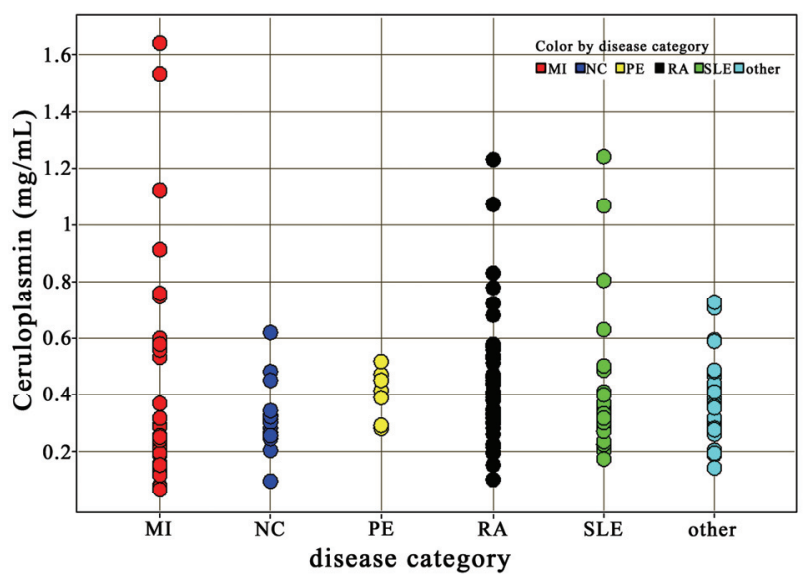

167 serum samples consist of $37 \mathrm{MI}$ (myocardial infarction), $16 \mathrm{NC}$ (normal controls), $8 \mathrm{PE}$ (pulmonary embolism), $50 \mathrm{RA}$ (rheumatoid arthritis), 24 SLE (systemic lupus erythematosus) and 32 other diseases (osteoarthitis, gout, dermatomyositis, ankylosing spondylitis, myositis, juvenile rheumatoid arthritis, etc)

Figure 3. $\mathrm{Cp}$ concentration for various diseases and normal controls. 


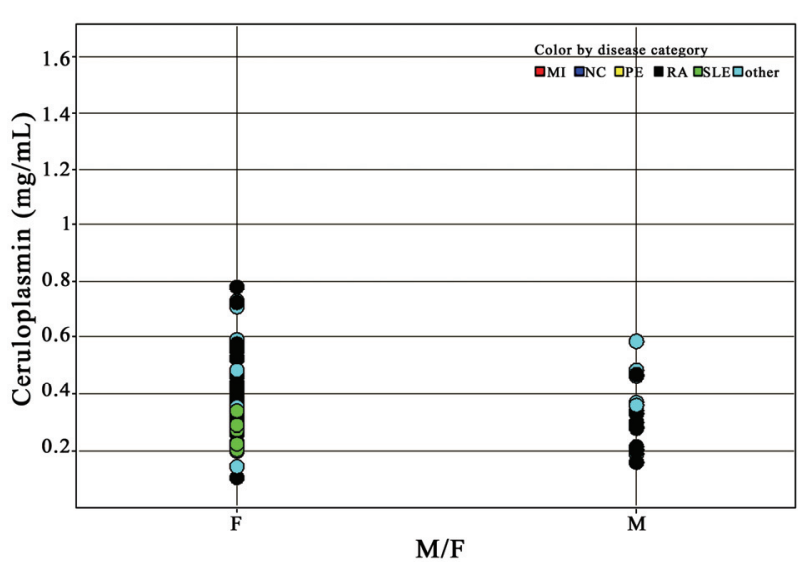

70 serum samples from 33 RA patients, 5 SLE, and 32 other diseases $\mathrm{M}$ - male (21 patients)

$\mathrm{F}$ - female (49 patients)

Figure 4. Cp concentration as a function of patient's gender.

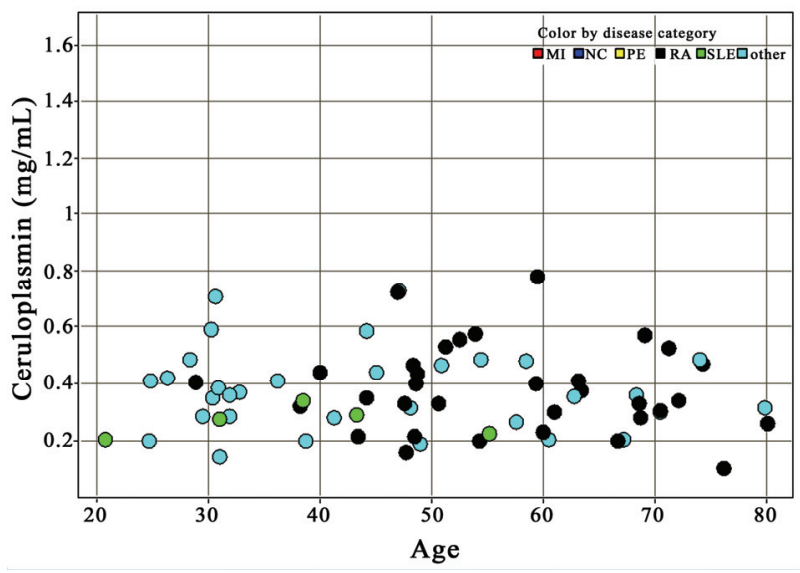

70 serum samples from 33 RA patients, 5 SLE, and 32 other diseases

Figure 5. Cp concentration as a function of patient's age.

results were not statistically significant). Results for a normal population indicated no age variation in adults [19], however in another study Revnic [21] reported differences $(\mathrm{p}<0.05)$ between $\mathrm{Cp}$ concentrations in RA patients $<50$ y.o. and $>70$ y.o. We have looked at $\mathrm{Cp}$ concentration for 22 RA patients $<50$ y.o. (12 patients) and $>66.6$ y.o (10 patients) and found no significant differences at $p<0.05$. Age related changes in human $\mathrm{Cp}$ concentrations were attributed to oxidative modifications, which can likely cause conformational changes around the $\mathrm{Cu}$ sites [22].

\section{CONCLUSIONS}

The method described here uses immunoaffinity chromatography and HPLC to separate $\mathrm{Cp}$ from the serum proteins prior to analysis by ICPMS. By removing the six most abundant proteins from serum with immunoaffinity chromatography and by using HPLC to separate $\mathrm{Cu}$ bound by $\mathrm{Cp}$ from any free $\mathrm{Cu}$ in the serum sample, we demonstrated that we can measure $\mathrm{Cp}$ in the ERM DA470 reference serum with an accuracy of 98 to $101 \%$. The HPLC-ICPMS method was used to analyze 167 serum samples from several diseases and a set of $\mathrm{NC}$ for $\mathrm{Cp}$. Our data for the 167 human sera show that $\mathrm{Cp}$ concentrations tend to be higher in MI, RA, and SLE patients. $\mathrm{Cp}$ concentrations were higher in female as compared to male patients, and this trend was most prominent in patients with RA. We did not observe a correlation between $\mathrm{Cp}$ concentration and patient's age for the limited set of 70 patients for which we had gender and age information. Thus, measurement of $\mathrm{Cp}$ levels by ICPMS represents a biomarker that when combined with conventional clinical and laboratory data may provide increased diagnostic value.

\section{ACKNOWLEDGEMENTS}

The authors thank Toshiaki Matsuda of Agilent Tokyo Analytical Division, Tokyo, Japan, for making available an ICPMS system for performing this research, Alex Apffel of Agilent Labs, Santa Clara, CA for making available an HPLC system with fraction collection and for assistance with the immunodepletion process.

\section{REFERENCES}

[1] Takahashi, N., Ortel, T., and Putnam, F. (1984) Single-chain structure of human ceruloplasmin: The complete amino acid sequence of the whole molecule. Proc Nat Acad Sci USA, 81, 390-4.

[2] Hellman, N.E. and Gitlin, J.D. (2002) Ceruloplasmin metabolism and function. Annu Rev Nutr, 22, 439-458.

[3] Hellman, N.E., Kono, S., Mancini, G.M., Hoogeboom, A.J., de Jong, G.J., and Gitlin, J.D. (2002) Mechanisms of copper incorporation into human ceruloplasmin. J Biol Chem, 48, 46632-46638.

[4] Linder, M.C., Wooten, L., Cerveza, P., Cotton, S., Shulze, R., and Lomeli, N. (1998) Copper transport. Am J Clin Nutr, 67, 965S-971S.

[5] Prohanska, J.R. and Gybina, A.A., (2004) Intracellular copper transport in mammals. J Nutr, 134, 1003-1006.

[6] DakoCytomation (1998) Application note guideline for determination of ceruloplasmin in serum/plasma on hitachi 911, 3 .

[7] Buffone, G.J., Brett, E.M., Lewis, S.A., Iosefson, M., and Hicks, J.M. (1979) Limitations of immunochemical measurement of ceruloplasmin. Clin Chem, 25, 749-51.

[8] Hohbadel, D.C., McNeely, M.D., and Sunderman, F.W. (1975) Automated bichromatic analysis of serum ceruloplasmin. Annals Clin Lab Sci, 5, 65-70.

[9] Twomey, P.J., Viljoen, A., House, I.M., Reynolds, T.M., Wierzbicki, A.S., (2005) Relationship between serum copper, ceruloplasmin, and non-ceruloplasmin -bound Copper in routine clinical practice. Clin Chem, 51, 1558-9.

[10] Macintyre, G., Gutfreund, K.S., Martin, W.R., Camicioli, R., Cox, D.W. (2004) Value of an enzymatic assay for the determination of serum ceruloplasmin. J. Lab. Clin. Med. 144, 294-301. 
[11] Hahn, S.-H., Jang, Y.-J., Lee, S.-Y., Shin, H.-C., Park, S.-Y., Yu, E.-S., and Han, H.-S. (2004) US patent $6,806,044$ B2-Method of measuring ceruloplasmin concentration in a blood spot, kit and method of diagnosing Wilson's disease.

[12] Newsome, D.A., Swartz, M., Leone, N.C., Hewitt, A.T., Wolford, F., and Miller, E.D. (1986) Macular degeneration and elevated serum ceruloplasmin. Investig Ophtalmol \&Visual Sci, 27, 1675-80.

[13] Reunanen, A., Knekt, P., and Aaran, R.K. (1992) Serum ceruloplasmin level and the risk of myocardial infarction and stroke. Amer J Epidemiol, 136, 1082-90.

[14] Interpath Laboratory, Inc. www.interpathlab.com/TechnicalUpdates/ceruloplasmin.htm (Accessed November 2006)

[15] Lopez-Avila, V., Robinson, W.H., and Sharpe, O. (2006) Determination of ceruloplasmin in human serum by SEC- ICPMS. Anal Bioanal Chem, 386, 180-7.

[16] Emons, H. (2005) Certificate of analysis ERM DA470, Institute for Reference Materials and Measurements, Geel, Belgium.

[17] Baudner, S., Bienvenu, J., Blirup-Jensen, S., Calstrom, A., Johnson, A.M., Milford Ward, A., et al. (2005) Certifica-

\section{Appendix}

\section{List of Abbreviations:}

$\mathrm{Cp}$ - ceruloplasmin

HPLC - high-pressure liquid chromatography

ICPMS - inductively-coupled plasma mass spectrometry

$\mathrm{MI}$ - myocardial infarction

$\mathrm{NC}$ - normal control tion report - The certification of a matrix reference material for immunochemical measurement of 15 serum proteins, institute for reference materials and measurements, Geel, Belgium.

[18] Hanzschel, H., Bird, H.A., Seidel, W., Kruger, W., Neumann, G., Schneider, G., and Wright, V. (1991) Polymyalgia rheumatica and rheumatoid arthritis of the elderly: A clinical, laboratory, and scintigraphic comparison. Annals of the Rheumatic Diseases, 50, 619-22.

[19] Lyngbye, J. and Kroll, J. (1971) Quantitative immunoelectrophoresis of protein in serum from a normal population: season-, age-, and sex-related variations. Clin Chem, 17, 495-500.

[20] Sontakke, A.N. and More, U. (2004) Changes in serum ceruloplasmin levels with commonly used methods of contraception. Indian J Clin Biochem, 19(1), 102-104.

[21] Revnic, F. (1995) The significance of serum ceruloplasmin in diagnosis of rheumatoid arthritis, Toxicol Lett, $7 \mathbf{8}$ (1), 70-71.

[22] Musci, G., Bonaccorsi, di Patti, M.C., Fagiolo, U., and Calabrese, L. (1993) Age-related changes in human ceruloplasmin, J Biol Chem, 268 (18), 13388-13395.
PE - pulmonary embolism

RA - rheumatoid arthritis

SLE - systemic lupus erythematosus

CREST- form of systemic sclerosis

ERM - European Reference Materials 